\title{
PERBINCANGAN MENGENAI HUKUMAN MATI TERPIDANA KASUS BALI NINE DAN MARY JANE DALAM SITUS JEJARING SOSIAL TWITTER
}

\author{
Jimi N. Mahameruaji, Teddy Kurnia Wirakusumah, \& Detta Rahmawan* \\ Program Studi TV dan Film, Fakultas Ilmu Komunikasi, Universitas Padjadjaran
}

\begin{abstract}
ABSTRAK
Twitter telah menjadi alat atau media komunikasi yang sangat populer diantara para pengguna Internet. Melalui Twitter, penggunanya dapat berbagi cerita hidup mereka sehari-hari, melakukan perbincangan dengan pengguna lain dan juga mengekspresikan pendapat mereka. Twitter juga dapat dilihat sebagai sebuah wadah untuk melakukan perbincangan politik dan isu-isu publik. Oleh karena itu, peran Twitter terkait partisipasi publik, kampanye, dan pembentukan opini publik kini semakin diperhitungkan (Jungherr, 2015). Fokus penelitian ini tentang perbincangan para pengguna Twitter di Indonesia mengenai peristiwa hukuman mati kasus narkoba Bali Nine dan Mary Jane. Penelitian ini bertujuan untuk mengetahui apa ragam perbincangan yang terjadi di antara para pengguna Twitter Indonesia terkait kasus hukuman mati tersebut, apa argumen yang muncul terkait penolakan maupun dukungan terhadap isu hukuman mati, dan juga siapa saja Twitter Influencer yang berperan dalam isu ini.
\end{abstract}

Kata-kata kunci: Twitter, ruang publik, hukuman mati, isu publik, analisis isi

\section{VARIOUS TALKS REGARDING THE CASE OF DEATH PENALTY ON BALI NINE AND MARY JANE IN TWITTER}

\begin{abstract}
Nowadays, Twitter is a popular platform that being used for various purposes. Twitter users could share the stories of their daily lives, talk with other users, and also express their opinions. Not only for mundane purposes, Twitter also can be seen as a sphere in which political and public issues are being talked and discussed. Hence, Twiter is considered as having important roles on public participation, political campaign, and the making of public opinion (Jungherr, 2015). This research focused on various talks in Twitter regarding the case of Death Penalty on Bali Nine and Mary Jane. This research tries to see what kind of talks occurs around Indonesian Twitter Users, and also analyze what kind of arguments that occured from users who supports and rejects death penalty. Finally, examples of Twitter Influencer who plays a role on the topic of death penalty also have been studied.
\end{abstract}

Keywords: Twitter, public sphere, and death penalty, public issue, content analysis

\section{PENDAHULUAN}

Beberapa waktu lalu, rencana eksekusi kasus anggota Bali Nine dan Mary Jane Veloso, warganegara Filipina yang menjadi terpidana mati kasus narkoba di Indonesia, menjadi tema perbincangan yang sangat hangat di kalangan masyarakat Indonesia. Sejak beberapa minggu sebelum rencana hukuman mati dilakukan pada tanggal 29 April (29/4) 2015, topik hukuman mati menjadi salah satu topik yang cukup ramai diberitakan di media-media massa nasional maupun internasional. Beberapa argumen, baik dari kalangan yang menyatakan dukungan hukuman mati, hingga yang menolak hukuman mati menjadi pemberitaan hampir semua media. Selain di media massa, kalangan masyarakat pun berpartisipasi dalam perbincangan ini dan mengemukakan pendapat mereka terkait hukuman mati dengan berbagai cara.

Tidak hanya dalam berbagai aksi nyata, perbincangan mengenai kasus hukuman mati juga kerap terjadi lewat ruang-ruang yang bersifat online atau terjadi dalam dunia maya. Misalnya saja dapat dilihat dari berbagai

\footnotetext{
* Korespondensi: Jimi N. Mahameruaji., S.Sos., M.Si. Program Studi TV dan Film, Fakultas Ilmu Komunikasi Universitas Padjadjaran, J1. Raya Bandung-Sumedang Km.21.Email: mahameruaji@gmail.com
} 
kampanye bertemakan "selamatkan Mary Jane" yang beredar di Internet. Salah satunya adalah dukungan yang disampaikan lewat petisi online di Change.Org (Manurung, 2015), dimana terdapat sekitar 270 ribu orang melakukan tandatangan secara online dan menyatakan bahwa Mary Jane tidak layak untuk dijatuhi hukuman mati, karena berbagai proses hukum yang ada dianggap tidak adil dan belum memadai. Kemudian di beberapa situs jejaring sosial yang populer di Indonesia seperti Facebook dan Twitter, antusiasme masyarakat luas dari berbagai kalangan terlihat dalam berbagai pertukaran pendapat mengenai Mary Jane dan topik hukuman mati serta berbagai keputusan hukum terkait permasalahan tersebut.

Terlepas dari segala kontroversi yang beredar terkaitkasus Bali Nine, Mary Jane dan permasalahan hukuman mati di Indonesia, riuhnya perbincangan yang dilakukan oleh masyarakat, terutama di media sosial dan situs jejaring sosial seperti Facebook dan Twitter menunjukkan tingginya keinginan masyarakat dalam mengikuti perkembangan topik tersebut. Segala bentuk ekspresi dan opini masyarakat dalam topik hukuman mati ini merupakan bagian dari perwujudan budaya partisipasi atau participatory culture terkait berbagai isu sosial dan politik yang lahir dalam masyarakat yang telah termediasi oleh adanya fasilitas user generated content dalam media digital (Jenkins, 2006).

Melalui berbagai situs jejaring sosial yang tersedia, masyarakat memiliki kebebasan untuk mengekspresikan dan menyampaikan pendapat di ruang publik. Dalam Twitter misalnya, mulai muncul aneka diskusi terbuka yang memungkinkan masyarakat untuk menyampaikan beragam argumen mengenai topik-topik yang bersifat publik. Oleh karena itu penelitian ini mencoba melihat seperti apa ragam perbincangan yang terjadi di antara para pengguna Twitter Indonesia terkait kasus hukuman mati tersebut, seperti apa argumen yang muncul terkait penolakan maupun dukungan terhadap isu hukuman mati, dan juga siapa saja Twitter Influencer yang berperan dalam isu ini.

Berbagai penelitian tentang Twitter selalu terkait dengan konteks pengguna yang berbeda-beda. Maksudnya adalah, habit, kebiasaan, pengguna Twitter di negara A belum tentu sama dengan pengguna Twitter di negara $\mathrm{B}$, dst. Indonesia sendiri adalah salah satu negara yang lansekap pengguna media sosialnya mengalami peningkatan pesat dalam beberapa tahun belakangan ini. Indonesia juga memiliki basis pengguna Twitter yang sangat besar (Semiocast, 2012; Lim, 2012). Sehingga dapat dikatakan bahwa penelitian tentang Twitter, dengan berbagai topik dan metode penelitian masih sangat relevan untuk dilakukan di Indonesia.

Kontroversi mengenai hukuman mati (Capital Punishment/Death Penalty) merupakan sebuah topik yang kontroversial dan terus diperdebatkan sejak dulu hingga saat ini. Tidak hanya di Indonesia, bahkan di Amerika dan Eropa, perdebatan mengenai perlu tidaknya dilakukan hukuman mati masih berlangsung lengkap dengan seperangkat argumennya masing-masing (Sani, 2015). Membicarakan hukuman mati kerap terkait dengan kasus narkoba, terutama mengenai peredaran narkoba di Asia Tenggara. Di Asia Tenggara terdapat sebuah kawasan yang dijuluki "Golden Triangle" atau kawasan segitiga emas yang melintasi Myanmar, Laos, dan Thailand. Kawasanini terkenal sebagaikawasan penghasil berbagai jenis narkotika, terutama jenis opium dan heroin (Wikipedia, 2016). Kasus hukuman mati di kawasan Asia Tenggara, terutama terkait dengan kasus narkoba menjadi sebuah hal yang selalu menjadi perhatian dunia.

Sebagai kawasan yang cukup sering disorot dunia terkait permasalahan narkotika, beberapa negara di kawasan ASEAN saat ini sedang berjuang keras untuk mengatasi peredaran narkotika dengan memperbaiki kemungkinan adanya penyelewengan dalam proses penegakan hukum, dan juga memperkeras hukuman bagi pihak-pihak yang terlibat dalam bisnis ini. Pada tahun 1980-1990-an, beberapa negara seperti Indonesia, Singapura, Vietnam, dan Malaysia memberlakukan hukuman mati yang cukup ketat, namun demikian hingga kini beberapa negara lain yang ada di kawasan Asia Tenggara tersebut seperti Myanmar, Filipina, Timor-Timur dan Kamboja dalam beberapa tahun terakhir tidak pernah melakukan hukuman mati, bahkan beberapa sudah menghapuskan hukuman mati di negaranya (Brennan, 2015). 
Menurut Soerjono Soekamto, publik merupakan kelompok yang tidak merupakan kesatuan. Interaksi dalam publik dapat terjadi secara tidak langsung melalui media komunikasi; baik media komunikasi secara umum misalnya pembicaraan-pembicaraan secara pribadi, desas-desus, maupun melalui media komunikasi massa seperti pers, radio, televisi, film dan sebagainya (Djoenaesih, 1984, hlm 19). Ruang publik harus bersifat otonom, sehingga memungkinkan warga untuk berkomunikasi dan menyatakan sikap terhadap problematika politik dan isu publik dengan bebas (Hardiman, 1993). Melalui Internet, kemudian banyak terbentuk ruang-ruang publik yang bersifat virtual. Dalam penelitian ini ruang publik yang dimaksud adalah Twitter. Twitter dipandang sebagai sebuah ruang virtual dimana penggunanya dapat melakukan diskusi dan menyatakan opini-opini mereka. Oleh karena itu penelitian ini melihat bahwa Twitter, melalui berbagai fitur yang dimilikinya, memberikan ruang tersebut pada masyarakat.

Perkembangan teknologi dan media baru menghasilkan perubahan besar dalam pengalaman politik masyarakat. Media baru yang dirancang untuk meningkatkan jangkauan, kecepatan dan efisiensi komunikasi manusia, memiliki potensi untuk memperkuat dan meningkatkan mutu demokrasi. Gagasan bahwa media, termasuk Internet, memberikan peluang lebih untuk partisipasi politik, memancing berbagai studi. Salah satu studi misalnya, menemukan bahwa dampak dari berita pemilu pada Internet meningkatkan kecenderungan orang akan memilih selama Pemilihan Presiden AS 1996 dan 2000, yang mengarah ke gagasan bahwa Internet memiliki potensi mobilisasi (Bakker \& Vreese, 2011).

Partisipasi sendiri dibagi atas partisipasi konvensional atau langsung, dan partisipasi online. Partisipasi konvensional pasif misalnya saja seperti, menerima buku atau informasi tentang politik, menandatangani petisi, dan mengikuti surat kabar dan televisi. Sedangkan Partisipasi konvensional aktif adalah mengirim surat pembaca ke koran atau majalah untuk mengomentari isu, mengirim surat atau menelepon untuk protes tentang keputusan yang diambil oleh pemerintah atau administrasi publik, berpartisipasi dalam demonstrasi, dan secara aktif terlibat dalam diskusi selama debat atau kuliah. Partisipasi digital pasif di sini diartikan seperti kegiatan membuka situs website kota/kabupaten, membuka situssitus pemerintah dan administrasi publik dan membuka situs dengan konten politik. Sementara itu partisipasi digital aktif adalah bereaksi untuk pesan atau artikel di Internet, menandatangani petisi secara online, dan berpartisipasi dalam jajak pendapat online (Bakker \& Vreese, 2011).

Berdasarkan berbagai uraian yang telah dipaparkan, maka masalah dalam penelitian ini dirumuskan sebagai berikut: "Seperti apa perbincangan mengenai hukuman mati terkait kasus Bali Nine dan Mary Jane terjadi dalam situs jejaring sosial Twitter?"

Dari rumusan penelitian yang telah disebutkan di atas maka dapat diidentifikasi beberapa pertanyaan penelitian sebagai berikut: (1) Tweet dukungan seperti apa saja yang muncul di Twitter terkait kasus hukuman mati Bali Nine dan Mary Jane di Indonesia? (2) Tweet penolakan seperti apa saja yang muncul di Twitter terkait kasus hukuman mati Bali Nine dan Mary Jane di Indonesia?, dan (3) Twitter Influencer seperti apa yang berpengaruh dalam kasus hukuman mati Bali Nine dan Mary Jane di Indonesia? Berdasarkan rumusan dan identifikasi masalah di atas, tujuan Studi tentang reaksi masyarakat terkait hukuman mati melalui situs jejaring sosial Twitter ini adalah: (1) Mengetahui Tweet dukungan seperti apa saja yang muncul di Twitter terkait kasus hukuman mati Bali Nine dan Mary Jane di Indonesia, (2) Mengetahui Tweet penolakan seperti apa saja yang muncul di Twitter terkait kasus hukuman mati Bali Nine dan Mary Jane di Indonesia, dan (3) Mengetahui Twitter Influencer seperti apa yang berpengaruh dalam kasus hukuman mati Bali Nine dan Mary Jane di Indonesia.

\section{METODE PENELITIAN}

Analisis isi merupakan sebuah metode penelitian yang digunakan untuk menganalisis semua bentuk komunikasi dari berbagai jenis media, seperti surat kabar, buku, puisi, lagu, cerita rakyat, lukisan, pidato, surat, peraturan, undang-undang, musik, teater, dll (Rakhmat, 
2012). Analisis isi merupakan sebuah metode penelitian yang tidak menggunakan manusia sebagai objek penelitian.

Analisis isi menggunakan simbol atau teks yang ada dalam media tertentu, untuk kemudian simbol-simbol atau teks tersebut diolah dan dianalisis. Selain itu analisis isi berupaya mengungkap berbagai informasi di balik data yang disajikan di media atau teks. Analisis isi dapat didefinisikan sebagai teknik mengumpulkan dan menganalisis isi dari suatu teks. Isi dalam hal ini dapat berupa kata, arti (makna), gambar, simbol, ide, tema, atau beberapa pesan yang dapat dikomunikasikan (Eriyanto, 2011).

Content analysis can be understood as a methodological framework within which various approaches of textual and non-textual analyses can be applied. The research technique of content analysis facilitates the systematic coding and analysing of the content of spoken, written, or audio-visual communication (Berelson, 1952; Krippendorff, 2004 dalam Einspänner, Dang-Anh, \& Thimm, 2014, 97).

Pada awalnya penggunaan metode analisis isi banyak dilakukan terutama dalam berbagai penelitian media cetak dan juga media massa konvensional lainnya. Namun seiring dengan berkembangnya teknologi, metode analisis isi mulai banyak digunakan dalam berbagai 'teks' yang ada dalam dunia online, seperti pada weblogs, chat forum, dll. Saat ini, dengan kemunculan berbagai media baru seperti media sosial Facebook dan Twitter, berbagai penelitian telah mengadaptasi metode analisis isi secara lebih fleksibel untuk dapat diterapkan dalam konteks penggunaan berbagai media sosial tersebut. Beberapa hal yang sering menjadi topik dalam analisis isi di Twitter misalnya, mengenai sentimen politik, perbandingan pembicaraan mengenai isu-isu publik, penggalian opini, dll (Thelwall, 2014; Einspänner, Dang-Anh, \& Thimm, 2014).

Objek dalam penelitian ini adalah segala perbincangan dalam bentuk tweet yang mengandung kata "hukuman mati" dan terkait dengan perbincangan Bali Nine dan Mary Jane sejak tanggal 1 April 2015 - 30 April 2015. Tweet dikelompokkan ke dalam dua kategori besar; argumen dukungan yang misalnya ditampilkan dengan kata- kata "dukung", "lanjutkan", dan argumen penolakan yang misalnya ditampilkan dengan kata-kata "tolak", "stop" dll. Selain itu penelitian ini juga melihat pemetaan dari berbagai aktor yang memiliki jumlah follower atau pengikut yang besar di Twitter, atau lazim disebut dengan Twitter Influencer (Marwick \& boyd, 2011; Jürgens \& Jungherr, 2011).

Data dikumpulkan mulai tanggal 1 April 2015 hingga 30 April 2015 yang diperoleh melalui penarikan data manual lewat fitur Twitter advanced search (Twitter, 2015) Sementara data sekunder diperoleh dari kajian kepustakaan, buku, jurnal ataupun informasi lain yang mampu membantu penelitian dan relevan dengan permasalahan yang diteliti. Setelah itu data yang ada kemudian diperiksa dan dibersihkan (dipilah) antara Tweet dari pengguna dengan spam, ataupun bentuk-bentuk Tweet lain yang tidak memenuhi syarat. Data kemudian disimpan, dan dipilah kembali dengan menggunakan Microsoft Excel untuk menggabungkan datadata yang identik, terutama username ${ }^{* *}$ yang bertumpuk dan pengurutan tanggal. Setelah itu, data disimpan untuk dianalisis secara kuantitatif dan kualitatif.

Analisis dan interpretasi data dalam penelitian ini dilakukan secara manual, menggunakan tiga tahap analisis. Pertama, dihitung jumlah data (user), dan kemudian dilakukan pengecekan user secara manual mencakup rasio follower-following dari akun tersebut. Kedua, percakapan yang terjadi di Twitter dikategorikan ke dalam tema-tema tertentu yang secara umum dibagi menjadi tiga (mendukung, menolak, dan netral) serta mencari kata yang paling banyak diulang oleh para pengguna Twitter untuk melihat reaksi khalayak terhadap program masing-masing kategori. Terakhir, peneliti mengkategorisasi tweet ke dalam tabulasi data untuk kemudian dianalisis dan diinterpretasi.

Mengingat banyaknya jumlah data yang dianalisis dalam penelitian ini, maka tahapan pertama penelitian ini adalah pendokumentasian dan pengumpulan data yang dilakukan secara manual. Tahap awal yang dilakukan adalah melakukan screen

\footnotetext{
* nama unik yang digunakan untuk mengakses sebuah sistem komputer, dalam konteks ini adalah untuk menggunakan Twitter
} 
capture pada hasil dari pencarian data lewat fitur Twitter Advanced Search dengan keyword atau kata kunci hukuman mati, kategori bahasa yang digunakan bahasa Indonesia, dan juga ditentukan tanggal dari penarikan data yang dilakukan. Dimana dalam tahap awal penelitian ini, supaya data yang diambil lebih presisi maka jangka waktu pengambilan data yang dipilih adalah lima hari, atau ada lima bagian dari keseluruhan jangka waktu pengambilan data (1 April-30 April 2015). Oleh karena itu pembagiannya adalah sebagai berikut: 1 April-5 April, 6 April-11 April, 12 April-17 April, 18-25 April, 26 April-30 April.

Dari hasil pengumpulan data yang telah dilakukan, terkumpul data mentah berupa Tweet yang mengandung kata "hukuman mati" sebanyak 25.609 buah. Hasil ini diperolah setelah melakukan pembersihan data tahap pertama, yaitu beberapa Tweet yang masuk kategori spam, dalam artian Tweet yang diulang-ulang oleh computer bot dan isinya di luar konteks, atau tidak relevan dengan kasus hukuman mati Bali Nine dan Mary Jane telah dibersihkan. Proses selanjutnya yang dilakukan oleh peneliti adalah melakukan pembersihan data tahap kedua, yaitu peneliti secara manual melakukan proses pemeriksaan ulang kepada 25.609 Tweet yang telah diperolah, dan kemudian melakukan proses pemilahan hingga data yang diperoleh adalah data real talk ${ }^{* * *}$ dari pengguna Twitter.

Proses pengumpulan data dan "pembersihan" tweet ini membutuhkan waktu yang cukup lama mengingat banyaknya data yang ada. Selain pembersihan Tweet dari berbagai macam spam, bot, dll, yang dilakukan selanjutnya adalah mencatat berbagai interaksi yang terjadi dalam satu Tweet seperti misalnya, berapa banyak yang melakukan reply (membalas), memberikan tanda bintang (favorit) atau melakukan Retweet. Namun dari berbagai data yang sudah terkumpul, dapat terlihat bahwa perbincangan mengenai topik hukuman mati yang dilakukan oleh masyarakat di Twitter mengalami kenaikan yang cukup signifikan menjelang saat pelaksanaan eksekusi mati (27-29 April 2015).

Dari hasil pembersihan data tahap kedua, terkumpul 7.848 Tweet $(\mathrm{N}=7.848)$ yang dianggap memenuhi syarat untuk

\footnotetext{
*** Data asli dari pengguna Twitter, bukan dari bot, bisa berupa Tweet, Reply, atau Retwee
}

dijadikan populasi penelitian ini. Data yang telah dikumpulkan, ditabulasi dan dimasukkan dalam bentuk program excel, untuk kemudian dilakukan proses penarikan sampling penelitian.

Proses penarikan sampling dalam penelitian ini dilakukan lewat beberapa pertimbangan berikut. Sebagai sebuah media sosial, Twitter adalah sebuah media yang memiliki beragam data yang dapat diteliti dan dianalisis, salah satunya adalah dengan menggunakan metode analisis isi. Melalui proses pengumpulan data dalam penelitian ini, diperoleh sejumlah 25.609 tweet pada hasil pembersihan data tahap pertama. Kemudian, dilakukan pembersihan tweet tahap kedua hingga terkumpul sebanyak, 7848 tweet yang dianggap sudah cukup bersih dan representatif. Karena keterbatasan waktu penelitian, dan juga tidak adanya software pengolah data yang dapat secara otomatis memilah data sebanyak itu, maka penelitian ini tidak dapat menganalisis 7848 tweet tersebut, sehingga perlu diberlakukan sebuah sampling.

Beberapa penelitian yang menggunakan Twitter sebagai objek penelitian kerap menggunakan software tertentu seperti Node XL, Crimson Hexagon, dll dalam proses pengumpulan data. Software ini digunakan secara otomatis menarik data yang jumlahnya ribuan atau bahkan lebih, sesuai dengan para-meter dan kategori yang sudah ditetapkan oleh peneliti (Jungherr, 2015). Penggunaan software ini tentunya dilakukan dengan pertimbangan untuk meminimalisir kesalahan yang dapat terjadi dalam pengumpulan data manual (Einspänner, Dang-Anh, \& Thimm, 2014).

Penarikan sampel dalam sebuah penelitian yang menggunakan Twitter sebagai objek penelitian bukanlah perkara mudah. Dari berbagai jurnal penelitian yang telah dicari terkait penelitian ini, sebagian besar sudah menggunakan software komputer pengolah data, sehingga prosedur sampling yang dilakukan dalam penelitian-penelitian tersebut tidak dapat secara langsung diterapkan dalam penelitian ini. Penggunaan teknik sampling yang tepat menjadi penting, supaya data yang ada dalam penelitian ini tetap dapat representatif dalam menggambarkan fenomena yang diteliti.

Sebelum melakukan penarikan sampling, peneliti memutuskan untuk membagi 7848 
Tweet yang sudah terkumpul ke dalam tiga kategori waktu berdasarkan tanggal tweet; yaitu kelompok kategori periode 1 sampai dengan 10 April, kelompok kategori periode 11 sampai dengan 20 April, dan kelompok kategori periode 21 sampai dengan 30 April. Pembagian ini dilakukan setelah melihat jumlah tweet secara keseluruhan, di mana terjadi kenaikan signifikan jumlah tweet di 10 hari terakhir. Pembagian ini juga digunakan berdasarkan penjelasan dari penelitian terdahulu terkait cara melihat sentimen publik di Twitter secara sederhana;

A simple way to analyse temporal trends in a Twitter corpus would be to sample a specified number of tweets at different time periods, such as at the beginning, middle, and end, and then use a content analysis (Neuendorf, 2002), to classify the samples. A comparison of the results at different time periods could then be used to identify changes over time (Thelwall, 2014, p. 87).

Data bersih yang telah dibagi menjadi tiga kategori waktu dapat dilihat dalam tabel berikut:

Tabel 1. Jumlah Tweet Keseluruhan

\begin{tabular}{ccc}
\hline No & Periode & Jumlah Tweet \\
\hline 1. & 1 April - 10 April & 453 \\
2. & 11 April - 20 April & 310 \\
3. & 21 April - 30 April & 7085 \\
\hline \multicolumn{2}{c}{ Total } & 7848 \\
\hline
\end{tabular}

Teknik sampling dalam penelitian ini dilakukan dengan menggunakan rumus Yamane, seperti dikemukakan dalam buku "Elementary Sampling Theory" (Yamane, 1967). Dengan perhitungan menggunakan rumus Yamane, dan tingkat error yang dapat diterima sebesar 5\%, maka diperoleh jumlah total sampling adalah sebanyak 381 Tweet. Selanjutnya dari 381 tweet tersebut akan dibagi ke dalam tiga kategori periode waktu secara proporsional sebagai berikut:

Tabel 2. Tweet Yang Menjadi Sampel

\begin{tabular}{ccc}
\hline No & Periode & Jumlah Tweet \\
\hline 1. & 1 April - 10 April & 22 \\
2. & 11 April - 20 April & 15 \\
3. & 21 April - 30 April & 344 \\
\hline & Total & 381 \\
\hline
\end{tabular}

Tahapan berikutnya adalah mengambil secara acak sejumlah tweet yang sudah ditentukan dari masing-masing kategori periode. Pada tahapan ini digunakan rumus (=RANDBETWEEN) di Microsoft Excel untuk mencari secara random tweet mana saja yang dapat diambil. Tentunya, sebelumnya tweet dalam masing-masing periode sudah diurutkan terlebih dahulu.

\section{HASIL DAN PEMBAHASAN}

Untuk melakukan pemilahan tweet ke dalam tiga kategori, maka dalam penelitian ini beberapa parameter yang digunakan adalah sebagai berikut: (1) Tweet yang menyatakan dukungan dalam pelaksanaan hukuman mati adalah Tweet, Reply Tweet, ataupun Retweet yang menggunakan kata-kata setuju, dukung, lanjutkan, teruskan, dll terkait dengan hukuman mati, (2) Tweet yang menyatakan penolakan dalam pelaksanaan hukuman mati adalah Tweet, Reply Tweet, ataupun Retweet yang menggunakan kata-kata:tidak setuju: tolak, jangan, stop, hentikan, dll terkait dengan hukuman mati, dan (3) Tweet yang bersifat Netral/Ambigu adalah Tweet, Reply Tweet, ataupun Retweet yang tidak menyatakan ketegasan, kebingungan, kekurang jelasan, ataupun mengalihkan pada topik lain.

Dengan menggunakan tiga parameter di atas, maka hasil dari analisis data yang telah dilakukan dapat dilihat dalam tabel berikut:

Tabel 3. Hasil Pengolahan Data

\begin{tabular}{ccc}
\hline No & \multicolumn{1}{c}{ Kategori } & Persentase \\
\hline 1. & Mendukung hukuman mati & 23 \\
2. & Menolak hukuman mati & 27 \\
3. & Netral atau ambigu & 50 \\
\hline & Total & 100 \\
\hline
\end{tabular}

Dari tabel 3 dapat dilihat bahwa, apabila tweet yang telah terkumpul dibagi ke dalam tiga kategori besar (mendukung, menolak, dan netral/ambigu) maka kategori dengan jumlah tweet terbanyak adalah tweet yang masuk dalam kategori netral/ambigu. Selanjutnya penelitian ini mencoba melihat secara detil seperti apa tweet yang berupa persetujuan, penolakan, dan tweet yang bersifat netral/ ambigu terhadap hukuman mati.

Dari hasil analisis yang telah dilakukan untuk melihat berbagai tema-tema yang ada dalam data yang tersedia, tidak ada topik 
dominan yang menjadi alasan utama terkait persetujuan pengguna Twitter terhadap hukuman mati. Namun beberapa topik yang dapat dielaborasi lebih lanjut adalah isu mengenai Penegakan hukum, Bahaya/Darurat narkoba, Ketegasan dan wibawa negara/pemerintah, dan Efek jera.

Isu penegakan hukum menjadi salah satu isu yang kerap didengungkan oleh mereka yang menyatakan persetujuan terhadap hukuman mati. Beberapa pengguna, baik secara implisit maupun eksplisit misalnya mengatakan bahwa pelaksanaan hukuman mati adalah bentuk penegakan hukum di Indonesia terkait narkoba. Mereka berpendapat bahwa narkoba adalah bentuk pelanggaran hukum yang sangat berat, sehingga diperlukan langkah nyata dari pemerintah terkait narkoba. Hal ini juga terkait dengan isu ketegasan pemerintah dan efek jera. Mereka yang mempunyai argumentasi terkait penegakan hukum juga banyak yang menyinggung mengenai keyakinan mereka bahwa hukuman mati akan menimbulkan efek jera terutama pada para pengedar narkoba yang mencoba untuk memasukkan narkoba ke Indonesia, dan juga hal ini akan membuat Indonesia menjadi disegani dan ditakuti oleh para pengedar ini.

Beberapa pengguna juga mengatakan bahwa jangan sampai Indonesia dianggap sebagai negara yang tidak tegas dan mau diatur oleh negara-negara lain, beberapa misalnya menyatakan ketidaksukaannya pada Australia, dan berbagai negara barat lain yang mencoba melakukan pendekatan pada Indonesia untuk menunda atau membatalkan hukuman mati. Mereka yang mendukung hukuman mati mengatakan bahwa saat inilah ketegasan dan wibawa Indonesia sebagai sebuah negara dipertaruhkan.

Hal lain yang juga menjadi perhatian cukup besar adalah mengenai persepsi bahwa Indonesia adalah negara darurat narkoba. Beberapa pengguna mengutip pernyataan presiden Jokowi yang menyatakan bahwa Indonesia saat ini ada dalam situasi darurat narkoba, dan merasa bahwa alasan ini menjadi alasan yang sahih bagi pelaksanaan hukuman mati di Indonesia. Menariknya, nyaris tidak ada yang mempertanyakan sumber dari pernyataan Jokowi tersebut, ataupun memberikan data lain. Alih-alih, beberapa diantara mereka menggunakan argumentasi dan justifikasi dari segi moral dan agama untuk menguatkan kesan darurat narkoba tersebut.

Contoh Tweet yang menyatakan persetujuan terhadap hukuman mati antara lain:

- \#IndonesiaKitaTerancam beri hukuman mati untuk pengedar narkoba saja takut Il padahal penduduk banyak rusak karena narkoba

- semoga ke depanya negara ini bisa. terbebas dri belenggu narkob semoga efek hukuman mati bisa bikin efek jera ke yg lainya.

- Salut untuk pemerintah Indonesia atas konsistensi HUKUMAN MATI terhadap terdakwa" pengedar narkoba d indonesia. SELAMATKAN INDONESIA! (sumber: dokumentasi peneliti)

Analisis deskriptif juga telah dilakukan untuk melihat berbagai tema-tema yang ada terkait bentuk-bentuk penolakan mengenai hukuman mati di Indonesia. Dari hasil analisis yang telah dilakukan terdapat tiga topik dominan yang menjadi alasan dari para pengguna Twitter yang menyatakan penolakan merekaterhadaphukumanmati. Beberapa topik yang dapat dielaborasi lebih lanjut adalah: (1) Ketidakjelasan sistem hukum terkait narkoba di Indonesia, (2) Ketidakpercayaan akan efek jera, (3) Hak Asasi Manusia

Salah satu tema dominan yang ada dalam beragam tweet terkait penolakan hukuman mati adalah mengenai masih lemahnya sistem hukum, terutama terkait masalah narkoba di Indonesia. Beberapa pengguna misalnya, dengan tegas memperlihatkan masih carutmarutnya sistem hukum terkait narkoba di Indonesia, baik terkait pemberantasan, penanggulangan, maupun tindakan preventif terkait narkoba. Selain itu, beberapa pengguna juga memperlihatkan bahwa hingga saat ini, sistem penjara dan lapas di Indonesia juga belum berfungsi dengan baik, dan para aparatnya pun dinilai masih banyak yang korup. Sehingga menurut mereka, hukuman mati adalah seperti sebuah jalan pintas yang tidak memiliki signifikansi apapun selain demi pertunjukan semu mengenai kewibawaan pemerintah.

Hal lain yang juga diperhatikan oleh para pengguna Twitter yang menolak dilaksanakannya hukuman mati di Indonesia 
adalah terkait ketidakpercayaan mereka akan efek jera yang dapat ditimbulkan dari adanya hukuman mati tersebut. Beberapa misalnya menggunakan data-data yang menyebutkan bahwa hukuman mati sebenarnya sudah dihapuskan di berbagai tempat karena berbagai penelitian ilmiah secara jelas mengungkapkan bahwa tidak ada korelasi signifikan antara hukuman mati dan efek jera dari pengedar narkoba.

Selanjutnya, argumen mengenai HAM (Hak Asasi Manusia) juga menjadi salah satu alasan penolakan hukuman mati. Beberapa pengguna percaya bahwa para pengedar masih memiliki hak untuk hidup, dan negara tidak berhak mencabut nyawa seseorang. Menariknya, argumen HAM menjadi salah satu argumen yang mendapat reaksi paling keras dari kubu pendukung hukuman mati. Beberapa misalnya mengatakan bahwa HAM adalah konsep yang kebarat-baratan dan tidak dapat diterapkan di Indonesia. Kemudian beberapa juga mengatakan bahwa para aktivis dan mereka yang memperjuangkan HAM adalah orang-orang yang pilih-pilih, terutama mempertanyakan komitmen mereka dalam kasus hukuman mati terdakwa terorisme seperti Amrozi cs.

Contoh Tweet yang menyatakan penolakan terhadap hukuman mati:

- Apa yg nasionalis sm hukuman mati? Hasilnya negatif utk kemajuan Indonesia apalagi utk TKI yg dihukum mati. Gmn bisa selamatkan mrk skrg?

- Hukuman mati tanpa adanya sistem hukum yang kuat, pasti tidak akan menjerakan para bandar narkoba untuk mengedarkan narkoba di Indonesia!

- Menolak hukuman MATI bukan berarti mendukung NARKOBA,untk bapak presiden @jokowi_do2 "u're not GOD who can take someone life" \#BiarkanHidup (sumber: dokumentasi peneliti)

Kategori selanjutnya yang telah di analisis adalah dari berbagai tweet yang memperlihatkan sikap netral/ambigu dalam melihat hukuman mati. Dari hasil analisis yang telah dilakukan kategori ini menjadi kategori terbesar yang ada. Hal ini dapat diinterpretasikan bahwa ternyata di Twitter pun banyak yang tidak mengungkapkan posisinya secara jelas, sehingga opini publik mengenai berbagai permasalahan atau isu publik ternyata tidak selalu terbagi dalam dua kubu secara rigid, cukup banyak diantara pengguna yang berpendapat diluar dari permasalahan setuju/ tidak tersebut.

Tingginya tingkat ambiguitas menjadi menarik, karena setelah ditelusuri lebih lanjut, banyak pengguna mengambil posisi di tengah dan tidak menunjukkan keberpihakan secara jelas dengan alasan merasa kekurangan informasi, merasa belum tahu mengenai kasusnya secara jelas, merasa bahwa hukuman mati tidak begitu penting dibandingkan isu pemberantasan narkoba secara keseluruhan, mengalihkan atau membandingkan dengan isu lain, dan lain sebagainya. Beberapa contoh tweet yang termasuk dalam kategori netral/ ambigu misalnya adalah:

- Mnrt sy ad dan tdknya hukuman mati tdk berpengaruh thdp HAM di indo, la dr dl pelaku HAM aja ga pernah ketangkap

- Protes kemarin itu pd hukuman mati atau vonis MJ? Klu pd hukuman mati, knp hashtagnya \#SaveMaryJane? Pdhal ada yg dari Indonesia.

-Bpk@Jokowi_Dodo,negara qt berlaku hukuman mati,jng hnygembongnarkoba,tp koruptor hrs d'hukum mati,jng pilih kasih antra warga dng pejabat

- Kloboleh brkomentarttg eksekusi hukuman mati narkoba, yg lbh esensi itu adlah aksi real stelah eksekusi.apa tindakan untuk brantas narkoba (sumber: dokumentasi peneliti)

Perdebatan mengenai siapakah sekelompok orang yang berpengaruh di Twitter (Twitter Influencer) telah menjadi topik penelitian yang cukup menarik. Berbagai penelitian memiliki definisinya sendiri-sendiri dalam menetapkan siapa yang pantas atau tidak pantas disebut sebagai Opinion Leader/ Prominent User/Influencer ini. Salah satu yang menjadi perhatian adalah bagaimana mendefinisikan secara operasional apa yang disebut dengan "influence" atau pengaruh, dalam konteks Twitter.

Dalam penelitian ini, kategori atau parameter yang digunakan untuk menentukan seorang Twitter Influencer adalah jumlah followers yang dimiliki, serta jumlah total 
dari pesan/mention yang diterima (Jürgens \& Jungherr, 2011; Marwick \& boyd, 2011). Dari kategori yang telah ditetapkan di atas, maka beberapa contoh Twitter Influencer yang memiliki pengaruh dalam konteks Hukuman Mati Bali Nine dan Mary Jane adalah sebagai berikut;

@Anggun_Cipta

Akun@Anggun_Cipta adalah akun pribadi milik Anggun C Sasmi, salah satu penyanyi berdarah Indonesia yang kiprah musiknya sudah diakui secara Internasional. Keterlibatan Anggun kepada isu hukuman mati di Indonesia dimulai saat ia menuliskan surat terbuka yang ditujukan kepada Presiden Jokowi perihal hukuman mati di Indonesia. Surat ini mendapat tanggapan yang sangat luas dari berbagai kalangan masyarakat dan juga media massa di Indonesia (Rappler, 2015).

Selain lewat Facebook, Anggun juga melakukan beberapa kali Twit yang berkaitan dengan hukuman mati tersebut. Namun dalam Twitter Anggun lebih menekankan lagi posisinya dalam memandang isu hukuman mati ini.

Anggun Official
ही. Anggun_Cipta
Untuk yang tdk mengerti, 2 poin yg penting di surat terbuka
saya : 1 . Saya anti Narkoba 2. Saya anti hukuman mati.
4:30 AM - 23 Apr 2015
\& $27139 \quad 119$

Sumber: dokumentasi peneliti

Seperti halnya suratnya di Facebook, para pengguna Twitter juga banyak yang kemudian membalas Twit Anggun, dan memberikan beberapa pendapat pribadinya. Ada yang mendukung, dan menyatakan persetujuan dengan sikap Anggun, dan ada pula yang secara keras menyatakan penolakan dan penentangan terhadapnya. Dalam analisis yang telah dilakukan, akun@Anggun_Cipta milik anggun ini memiliki jumlah followers paling tinggi dan sekaligus juga mendapatkan jumlah interaksi paling tinggi diantara akun-akun lain dalam konteks pembicaraan hukuman mati Bali Nine dan Mary Jane. Contohnya, salah satu Tweet dari anggun di atas berhasil menarik perhatian banyak pengguna Twitter lain dan mendapat 139 Retweet, 119 Favorite dan ratusan reply dari para pengguna lain yang mengemukakan pendapatnya.
@) Rahung

Rahung Nasution adalah salah seorang selebtwit (Rahmawan, 2014) di Indonesia yang berprofesi sebagai seorang koki dan budayawan. Selama bulan April, ia termasuk salah satu yang paling getol mengutarakan ketidakpersetujuannya akan hukuman mati lewat Twitter. Ia mengemukakan alasannya menolak hukuman mati dari berbagai sudut pandang seperti hukum dan politik di Indonesia serta juga terkait dengan argumen-argumen hak asasi manusia, dan ketakutannya bahwa hukuman mati di Indonesia akan memberikan efek negatif bagi para TKI yang terkena kasus di luar negeri.

Berikut beberapa contoh Tweet dari Rahung:

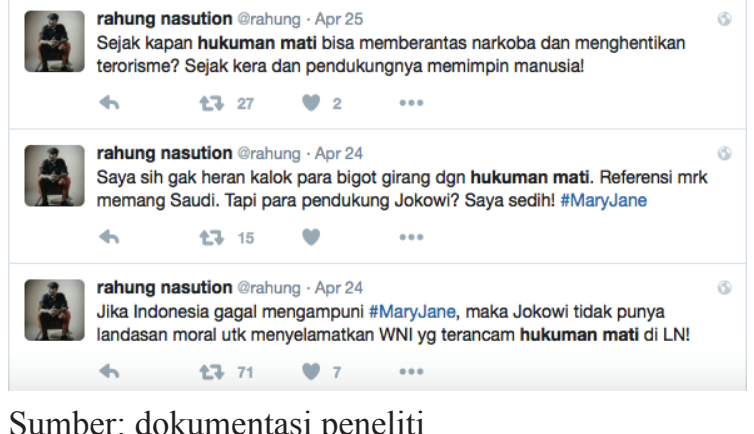

Sumber: dokumentasi peneliti

Meskipun tidak memiliki jumlah interaksi sebanyak Anggun dan akun Twitternya@Anggun_Cipta, dengan sekitar 23.000 follower yang ia miliki, Rahung Nasution tetap dianggap memiliki influence atau pengaruh yang cukup tinggi sebagai salah satu Twitter Influencer terkait kasus hukuman mati Bali Nine dan Mary Jane.

@Kurawa

Akun@Kurawa mulai ramai diperbincangkan dalam dunia online, terutama menjelangPilpres2014.Saatituakun@Kurawa menjadi salah satu akun yang menyatakan dukungannya terhadap Joko Widodo, dan dianggap sebagai salah satu opinion leader dalam bidang perbincangan politik. Namun sebenarnya tidak pernah ada dokumen jelas mengenai siapa sebenarnya orang dibalik akun @ Kurawa ini. Pada akunnya ia menggunakan nama Rudi Valinka. Namun, tidak pernah ada pemberitaan, dokumen, atau catatan apapun mengenai nama tersebut. Meskipun demikian, dilihat dari jumlah follower, kemudian lewat interaksi dari para followernya, dapat dilihat bahwa ia termasuk salah satu akun bernuansa 
politik yang cukup berpengaruh di Twitter. Berikut beberapa contoh Twit dari akun @ Kurawa terkait isu hukuman mati Bali Nine dan Mary Jane:

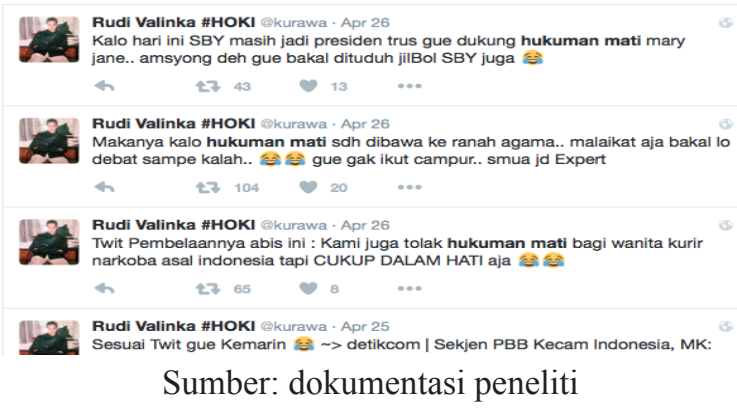

Terkait isu hukuman mati Bali Nine dan Mary Jane ia adalah salah satu tokoh di Twitter yang menyuarakan persetujuan terhadap hukuman mati. Bahkan dalam menyuarakan persetujuannya akan hukuman mati ini ia tidak sungkan untuk melakukan debat atau membalas Tweet dari para pengguna lain yang menolak hukuman mati. Misalnya saja, ia pernah terlihat melakukan tweet yang bernada provokatif terhadap politisi Partai Demokrat Ulil Ashar Abdalla, yang menyuarakan penolakan hukuman mati lewat akun Twitternya @Ulil.

Udi Valinka \#HOKI Dkurawa · Apr 27

cc : @ulil shameOnYou upil > Eksekusi Hukuman Mati Terbanyak di Era SBYJK - Kompas.com Tekno tekno.kompas.com/read/2008/10/3... ᄂ7 $63 \cup 14 \quad \cdots$

Sumber: dokumentasi peneliti

Gaya akun@Kurawa dalam melakukan tweet nya terkait berbagai isu biasanya jarang menampilkan link kepada data atau artikel yang membutuhkan pembacaan lebih jauh, namun ia cenderung mengemas pendapatnya secara singkat, padat dan tidak memakai pilihan kata yang rumit sehingga relatif lebih mudah dipahami. Ia juga cukup sering menggunakan bahasa kasar dan juga bentukbentuk komunikasi yang bersifat humoris. Meskipun kredibilitasnya dapat dipertanyakan, dan juga keabsahan data-data yang ia sebutkan juga masih belum terbukti kebenarannya. Namun terlepas dari segala kontroversi tersebut, pada kenyataannya dengan hampir 135 ribu follower yang ia miliki, akun@ Kurawa pantas dimasukkan sebagai salah satu Twitter Influencer dalam kasus hukuman mati Bali Nine dan Mary Jane ini.

Penelitian mengenai adanya sekelompok orang yang memiliki pengaruh besar di Twitter atau disebut dengan Opinion Leader/
Prominent User/Influencer telah cukup banyak dilakukan (Marwick \& boyd, 2011; Jungherr, 2015). Telah diulas tiga contoh dari Influencer terkait dengan isu hukuman mati Bali Nine dan Mary Jane, baik dari pihak yang menolak maupun yang mendukung hukuman mati. Ketiga contoh akun yang telah dipaparkan di atas menjadi gambaran seklilas dari beberapa influencer yang memiliki pengaruh cukup besar terhadap followers yang mereka miliki, dan kehadiran mereka juga mendapatkan perhatian besar, baik secara pro maupun kontra, dari para pengguna Twitter lainnya. Namun tentu saja diperlukan penelitian secara khusus mengenai Influencer ini untuk melihat secara lebih detil beragam bentuk pengaruh dari akun-akun tersebut.

\section{SIMPULAN}

Dengan menggunakan metode analisis isi, hasil analisis data yang telah dilakukan menunjukkan kesimpulan sebagai berikut: 1) Sejumlah $23 \%$ pengguna mendukung hukuman mati dengan contoh argumen yang dikemukakan terkait bahwa hukuman mati adalah bentuk penegakan hukum, kecemasan mengenai bahaya/darurat narkoba di Indonesia, hukuman mati adalah bentuk ketegasan dan wibawa negara/pemerintah, serta efek jera. 2) Sebanyak $27 \%$ menolak hukuman mati dengan berbagai alasan seperti; ketidakjelasan sistem hukum terkait narkoba di Indonesia, ketidakpercayaan akan efek jera dari hukuman mati, dan persoalan Hak Asasi Manusia. 3) Ditemukan beberapa Twitter Influencer yang berperan dalam penggiringan opini publik seperti@Anggun_Cipta,@Rahung dan@ Kurawa.

Sekelompok orang yang memiliki pengaruh besar di Twitter dapat disebut dengan Opinion Leader/Prominent User/Influencer (Marwick \& boyd, 2011; Jungherr, 2015). @ Anggun_Cipta dan@Rahung dapat dikatakan sebagai Influencer dari pihak yang menolak hukuman mati, sedangkan akun@Kurawa adalah Influencer yang mendukung hukuman mati. Dari hasil ulasan dan analisis data yang tersedia, ketiga contoh akun ini menjadi gambaran dari beberapa Twitter Influencer dalam kasus hukuman mati Bali Nine dan Mary Jane, yang memiliki pengaruh cukup 
besar terhadap followers yang mereka miliki. Terlihat bahwa berbagai Tweet mereka mendapatkan perhatian besar, baik secara pro maupun kontra, dari para pengguna Twitter lainnya. Hal menarik yang juga didapatkan dalam penelitian ini adalah tingginya tingkat ambiguitas yang ada, dimana menurut data yang ada, dalam konteks pembicaraan terkait hukuman mati ini, polarisasi pendapat ternyata tidak selalu terjadi. Setelah ditelusuri lebih lanjut, data yang ada memperlihatkan bahwa banyak pengguna mengambil posisi netral dan tidak menunjukkan keberpihakan secara jelas, karena merasa kekurangan informasi dan merasa belum tahu mengenai detil kasusnya secara jelas.

Media sosial sebagai topik dan konteks penelitian ilmu komunikasi telah berkembang secara sangat pesat. Penelitian mengenai Twitter telah dilakukan dengan beragam metode, dan juga dengan beragam topik. Khususnya, penelitian mengenai perbincangan, sentimen politik, di linimasa Twitter dengan menggunakan metode analisis isi juga adalah salah satu penelitian yang berkembang. Namun penelitian ini memiliki keterbatasan dalam hal belum digunakannya software analisis pengolahan data, sehingga diperlukan waktu yang lama untuk pengumpulan data, dan pada akhirnya analisis dilakukan tidak secara keseluruhan namun lewat sampel penelitian. Saran untuk penelitian selanjutnya dengan topik atau tema sejenis adalah melakukan penelitian dengan menggunakan software analisis pengolahan data, atau juga dengan menggunakan metode lain seperti etnografi, untuk melihat gambaran dari bagaimana suatu isu berkembang dan dibicarakan secara luas di linimasa Twitter secara lebih komprehensif.

\section{DAFTAR PUSTAKA}

Bakker, P. T., \& Vreese, H. C. (2011). Good News for the Future? Young People, Internet Use, and Political Participation. Communication research , 20 (10), 1-20.

Berelson, B. (1952). Content analysis in communication research. New York: Free Press.
Brennan,E.(2015,January23).Thedeathpenalty in southeast asial. Dipetik pada Mei 5, 2015, dari Lowly Interpreter: http://www. lowyinterpreter.org/post/2015/01/23/ The-death-penalty-in-Southeast-Asia. aspx?COLLCC $=4109196824 \&$

Djoenaesih, S. S. (1984). Opini publik. Yogyakarta: Liberty.

Einspänner, J., Dang-Anh, M., \& Thimm, C. (2014). Computer-Assisted Content Analysis of Twitter Data. Dalam K. Weller, A. Bruns, M. Mahrt, \& C. Puschmann (Penyunt.). Twitter and society (hal. 97). New York: Peter Lang.

Eriyanto. (2011). Analisis pengantar metodologi untuk penelitian ilmu komunikasi dan ilmu-ilmu sosial lainnya. Jakarta: Kencana Prenada Media Group.

Hardiman, F. (1993). Menuju masyarakat komunikatif. Yogyakarta: Kanisius.

Jenkins, H. (2006). Convergence culture. New York: NYU Press.

Jungherr, A. (2015). Analyzing political communication with digital trace data: the role of twitter messages in social science research. Switzerland: Springer International Publishing.

Jürgens, P., \& Jungherr, A. (2011). Wahlkampf vom Sofa aus: Twitter im Bundestagswahlkampf 2009. Dalam E. Schweitzer, \& S. Albrecht (Penyunt.), Das Internet imWahlkampf: Analysen zur Bundestagswahl 2009. VS Verlag für Sozialwissenschaft, (hal. 201-225.). Wiesbaden.

Krippendorff, K. (2004). Content analysis: an introduction to its methodology. Thousand Oaks, CA: Sage.

Lim, M. (2012). Many Clicks but Little Sticks: Social Media Activism in Indonesia. Journal of contemporary asia.

Manurung, R. (2015). Presiden jokowi do2 aku memilihmu untuk ham tolong jangan bunuh korban perdagangan manusia selamatkanmaryjane. Dipetik darihttps:// www.change.org/p/presiden-jokowi- 
do2-aku-memilihmu-untuk-ham-tolongjangan-bunuh-korban-perdaganganmanusia-selamatkan-maryjane

Marwick, A., \& boyd, d. (2011). To See and Be Seen:Celebrity Practise On Twitter. Convergence: the international journal research into new media technologies, 17 (2), 139-158.

Neuendorf, K. (2002). The content analysis guidebook. London, UK: Sage. London: Sage.

Rahmawan, D. (2014). Selebtwit: MicroCelebrity in Indonesian Twittersphere. Jurnal kajian komunikasi , 2 (1), 1-11.

Rakhmat, J. (2012). Metode penelitian komunikasi. Bandung: Remaja Rosdakarya.

Rappler. (2015). Anggun: pak jokowi saya tidak setuju hukuman mati. Dipetik dari http://www.rappler.com/world/regions/ asia-pacific/indonesia/90887-anggunpak-jokowi-saya-tidak-setuju-hukumanmati
Sani, A. (2015). Kontroversi hukuman mati broleh-arsul sani. Dipetik pada 5 Juni 2015, dari hukumonline.com: http://www.hukumonline.com/berita/ baca/lt54a692f2c80be/kontroversihukuman-mati-broleh--arsul-sani-

Semiocast. (2012). Semiocast. Dipetik pada 15 Januari 2015 dari http://semiocast. com/en/publications/2012_07_30 Twitter_reaches_half_a_billion_accounts_140m_in_the_US

Thelwall, M. (2014). Sentiment Analysis and Time Series with Twitter. Dalam K. Weller, A. Bruns, M. Mahrt, \& C. Puschmann (Penyunt.). Twitter and society (hal. 83). New York: Peter Lang.

Wikipedia. (2016). Golden triangle (southeast asia). Diakses dari http://en.wikipedia. org/wiki/Golden_Triangle_(Southeast_ Asia)

Yamane, T. (1967). Elementary sampling theory. Englewood Cliffs, New Jersey: Prentice-Hall, Inc. 